九州大学学術情報リポジトリ

Kyushu University Institutional Repository

\title{
Mycelium Growth and Biological Efficiency of Ganoderma lucidum on Substrate Supplemented with Different Organic Additives
}

Lisiecka, Jolanta

Department of Vegetable Crops, Poznan University of Life Sciences | Laboratory of Forest Resources Management, Division of Forest Environmental Sciences, Department of Agroenvironmental Sciences, Faculty of Agriculture, Kyushu University

Rogalski, Jerzy

Department of Biochemistry, Maria Curie-Skłodowska University

Sobieralski, Krzysztof

Department of Vegetable Crops, Poznan University of Life Sciences

Siwulski, Marek

Department of Vegetable Crops, Poznan University of Life Sciences

他

https://doi.org/10.5109/1526342

出版情報: 九州大学大学院農学研究院紀要. 60 (2)，pp.303-308，2015-09-18. Faculty of Agriculture, Kyushu University

バージョン：

権利関係 : 


\title{
Mycelium Growth and Biological Efficiency of Ganoderma lucidum on Substrate Supplemented with Different Organic Additives
}

\author{
Jolanta LISIECKA ${ }^{1 *}$, Jerzy ROGALSKI ${ }^{2}$, Krzysztof SOBIERALSKI ${ }^{1}$, \\ Marek SIWULSKI ${ }^{1}$, Sławomir SOKÓ $\mathfrak{E}^{3}$ and Shoji OHGA* \\ Laboratory of Forest Resources Management, Division of Forest Environmental Sciences, \\ Department of Agro-environmental Sciences, Faculty of Agriculture, \\ Kyushu University, Sasaguri, Fukuoka 811-2415, Japan \\ (Received April 14, 2015 and accepted May 19, 2015)
}

\begin{abstract}
Ganoderma lucidum (W. Curt.: Fr) P. Karst. is a mushroom exhibiting various medicinal properties, popular particularly in Asia. It is grown on a substrate based on hardwood sawdust. Other organic materials, usually agricultural or industrial waste supplemented with various additives, are also used in the cultivation of this mushroom. Numerous studies have shown that the composition of the substrate has a significant effect on mycelium growth and biological efficiency of Reishi mushroom. The presented analysis determined the effect of different organic substances on mycelium growth and biological efficiency of several $G$. lucidum isolates (Gan 18, Gan Li 27/3, Gan 7, Gan 112) obtained from mushrooms growing in the wild and from strains of this mushroom (GL 01, GL 02, GL 03 and GL 04). Growing substrate containing oak sawdust supplemented with wheat bran (20\%), rye grain (25\%), ground soy (7\%), ground rapeseed (10\%) or meatand-bone meal (10\%). These additives had a considerable effect on mycelium growth and its biological efficiency. A different response to sawdust substrate additives was found for the group of isolates and strains of $G$. lucidum. All the additives, except for meat-and-bone meal, had a positive effect on mycelium growth and its biological efficiency. In the case of G. lucidum strains a more rapid mycelium growth and a greater biological efficiency were observed for its isolates collected from nature, irrespective of the type of substrate additive.
\end{abstract}

Key words: Ganoderma lucidum, agro-industrial residues, mycelium growth, biological efficiency

\section{INTRODUCTION}

Ganoderma lucidum (W. Curt.: Fr.) P. Karst. (in China known as Ling Zhi and in Japan as Reishi) is one of the most popular medicinal mushrooms in China, Japan, Korea and other Asian countries (Stamets, 2000; Chang and Miles, 2004; Zhou et al., 2012). Numerous studies have shown that Reishi mushroom contains several pharmacologically active substances (Wasser, 2005, 2011; Paterson, 2006; Boh et al., 2007). Medicinal properties of G. lucidum are connected first of all with its anticancer and immunomodulatory effects (Wasser, 2002; Sanodiya et al., 2009; Xu et al., 2011; Batra et al., 2013). Numerous preparations based on G. lucidum are commercially available worldwide and the observed demand for these products shows a marked upward trend (Lai et al., 2004).

Ganoderma lucidum grows on dead trees of many species, mainly deciduous (hardwood), while it is rather rarely found in coniferous (softwood) species (Stamets, 2000; Chen, 2002; Wasser, 2005). As it was reported by Curvetto et al. (2002), Hsieh and Yang (2004) and Sanodiya et al. (2009), in order to meet the increasing

Department of Vegetable Crops, Poznan University of Life Sciences, Dąbrowskiego 159, 60-594 Poznań, Poland

${ }^{2}$ Department of Biochemistry, Maria Curie-Skłodowska University, Akademicka 19, 20-033 Lublin, Poland

Department of Biosystematics, Opole University, Oleska 22, 45-052 Opole, Poland

* Corresponding authors (E-mail: ohga@forest.kyushu-u.ac.jp, lisica@up.poznan.pl) demand this species is grown on different natural solid substrates as well as liquid nutrient media. Fruit bodies of $G$. lucidum are traditionally produced on wood, sawdust and grain (Stamets, 2000; Chen, 2002 2004; Wasser, 2005; Boh et al., 2007; Azizi et al., 2012). As it was reported by Sukarno et al. (2009), hardwood is particularly useful in this case. In the culture of G. lucidum other organic materials are also used, most frequently agricultural or industrial waste, e.g. sunflower husks (Gonzalez-Matute et al., 2002), coir (Mishra and Singh, 2008), different types of straw (Mishra and Singh, 2008; Ke et al., 2011; Veena and Pandey, 2011) as well as hemp and flax shives (Siwulski et al., 2010). Numerous studies have shown that the application of such substrate additives as wheat, rice or maize bran (Chen, 2004; Erkel, 2009a; Azizi et al., 2012), corn meal and gram flour (Gurung et al., 2012), tea waste (Peksen and Yakupoglu, 2009), soy residue (Hsieh and Yang, 2004), molasses (Stamets, 2000; Erkel 2009b), malt (Gonzalez-Matute et al., 2002), stillage grain (Yang et al., 2003), yeasts (Ke et al., 2011), food waste compost (Jo et al., 2013a,b) and fishing industry waste (Lakshmi, 2013) may improve yields of Reishi mushrooms. The effect of these additives on yielding depends first of all on their contents of nitrogen sources and the supply of carbon compounds available for mycelium (Hsieh and Yang, 2004; Erkel, 2009b; Peksen and Yakupoglu, 2009; Jo et al., 2013a).

Many studies showed an effect of cultivation conditions and the composition of the substrate on mycelium growth, biological efficiency and contents of bioactive compounds in Reishi mushrooms (Siwulski and 
Sobieralski, 2001; Hsieh and Yang, 2004; Rai et al., 2004; Sobieralski and Grzebielucha, 2005, 2006a,b; Boh et al., 2007; Mishra and Singh, 2008; Erkel 2009a; Peksen and Yakupoglu, 2009; Siwulski et al., 2010; Skalicka-Woźniak et al., 2012). Philippoussis et al. (2001), Peksen and Yakupoglu (2009) as well as Fanadzo et al. (2010) showed an effect of physical and chemical properties of the cultivation substrate on the yielding level and biological efficiency in many fungal species. The period of substrate overgrowth is also a very important indicator, since to a considerable extent it determines the economic effects of culture. Substrates, which are slowly overgrown by mycelium, are susceptible to fungal and bacterial infections and this results in a decreased yielding (Philippoussis et al., 2001).

The aim of the presented study was to determine the effect of different organic additives on mycelium growth and biological efficiency of selected wild G. lucidum isolates and the culture collection strains.

\section{MATERIAL AND METHODS}

The analyses were conducted on four isolates (Gan 18, Gan Li 27/3, Gan 7 and Gan 112) and four strains of G. lucidum (GL 01, GL 02, GL 03 and GL 04) coming from the collection of cultivated and medicinal fungi of the Department of Vegetable Crops, the Poznan University of Life Sciences.

Mycelium growth and biological efficiency of $G$. lucidum were tested on solid substrate containing $Q$. robur L. sawdust (the $0.5-3 \mathrm{~mm}$ fraction at $80 \%$, the $0.3-$ $0.4 \mathrm{~mm}$ fraction at $10 \%,<0.3 \mathrm{~mm}$ at $10 \%$ ), which were supplemented with $20 \%$ wheat bran, $25 \%$ rye grain (cv. 'Słowiańskie'), 7\% ground soy, 10\% ground rapeseed or $6 \%$ meat-and-bone meal (w/w). All additives came from MŁYNPASZ Sp. z o.o,, Poland. At the application of the above mentioned amounts of additives the substrates contained a comparable amount of protein, i.e. $3.2 \mathrm{~g}$ per $100 \mathrm{~g}$ d.m. substrate. The amount of protein in additives was calculated on the basis of the analyses of total nitrogen contents according to Kjeldahl using the N x 6.25 conversion factor. The control comprised oak sawdust substrate with no additives. After all the components in the substrates were mixed in, moisture content was determined by the gravimetric method $\left(105^{\circ} \mathrm{C}\right)$. Based on the known water contents in the mixtures they were moistened with tap water until 60\% moisture content was obtained.

\section{Mycelium growth}

Glass test tubes of $1.5 \mathrm{~cm}$ in diameter and $16 \mathrm{~cm}$ in length were filled with previously produced substrates to the height of $12 \mathrm{~cm}$ and next sealed with cotton wool stops. The test tubes with substrates were sterilized in $121^{\circ} \mathrm{C}$ at $0.1 \mathrm{MPa}$ for $1 \mathrm{~h}$. After cooling the substrates to room temperature (ca. $21^{\circ} \mathrm{C}$ ) a $1-\mathrm{cm}$ layer of mycelium on wheat grain was placed on the top of substrate. The incubation process was run for 14 days at $25^{\circ} \mathrm{C}$ and $80-$ $85 \%$ relative humidity, with no access to light. Mycelium growth was measured accurate to $1 \mathrm{~mm}$ after incubation was completed. A measure of growth was determined by the thickness of the substrate layer overgrown by mycelium. The experiment was run in a random design in two series of five replications each.

\section{Biological efficiency}

Polypropylene culture bags equipped with a microbiological filter (Fungi Laboratories, Spyra, Poland) were filled with $2.5 \mathrm{~kg}$ previously produced substrates and sterilized in $121^{\circ} \mathrm{C}$ at $0.1 \mathrm{MPa}$ for $1.5 \mathrm{~h}$. After the substrates cooled to room temperature (ca. $21^{\circ} \mathrm{C}$ ) they were spawned with mycelium on wheat grain at $50 \mathrm{~g}$ per bag. Bags were sealed using a sealer (Impuls Sealer KSA-450, Poland), incubated in an incubation chamber (Pol-EkoAparatura, ST-500) with no access to light at a temperature of $25^{\circ} \mathrm{C}$ and $90-95 \%$ relative humidity until the substrate was completely overgrown by mycelium. After complete substrate overgrowth by mycelium the plastic was removed from the bags up to the upper substrate surface. Next bags were transferred to a cultivation chamber, in which the temperature of $23^{\circ} \mathrm{C} \pm 1^{\circ}$ and $85-90 \%$ relative humidity were maintained, and lighting was provided by Day-Light fluorescent light (40W lamps, Osram, Germany) at $500 \mathrm{~lx}$ for $12 \mathrm{~h}$ per day. Fruit bodies were harvested as they were growing and maturing, cutting them at the stipe base. Biological efficiency (BE) expressed in (\%) was equivalent to the weight of fresh fruit bodies per $100 \mathrm{~g}$ substrate dry weight. The experiment was run in a random design in two growing cycles with five replications each.

\section{Statistical analysis}

Results were subjected to the analysis of variance for factorial experiments. The significance of differences between the tested factors was determined using the Newman-Keuls test at $\alpha=0.05$.

\section{RESULTS AND DISCUSSION}

\section{Mycelium growth}

Statistical analysis of recorded results showed a significant effect of organic additives used in solid substrate with oak sawdust on mycelium growth of isolates and strains of G. lucidum (Table 1). It was found that four among the applied agri-food products (wheat bran, rye grain as well as ground soy and ground rapeseed) had an advantageous effect on mycelium growth. In turn, an addition of meat-and-bone meal did not result in increased mycelium growth rates of tested isolates and strains of G. lucidum.

Chen (1999) in mycelium of Ganoderma growing on oak sawdust substrate reported the best growth of the tested mushroom in the variant with an $18 \%$ addition of wheat bran. Rai et al. (2004) and Sobieralski and Grzebielucha (2005) reported in their studies that the mycelium growth rate of Reishi mushroom increases with an increase in the amount of bran added to the substrate. However, an addition exceeding 20\% reduced mycelium growth rate. For this reason in this study this substance was added at 20\% concentration. The observed 
Table 1. Mycelium growth of isolates and strains of Ganoderma lucidum on oak sawdust substrate supplemented with different organic additives after 14 days of incubation

\begin{tabular}{lcccccc}
\hline & \multicolumn{5}{c}{ Organic additives } \\
\cline { 2 - 6 } $\begin{array}{c}\text { Isolates/ } \\
\text { strains }\end{array}$ & $\begin{array}{c}0 \% \\
\text { control }\end{array}$ & $\begin{array}{c}20 \% \\
\text { wheat bran }\end{array}$ & $\begin{array}{c}25 \% \\
\text { rye } \\
\text { grain }\end{array}$ & $\begin{array}{c}7 \% \\
\text { ground } \\
\text { soy }\end{array}$ & $\begin{array}{c}10 \% \\
\text { ground } \\
\text { rapeseed }\end{array}$ & $\begin{array}{c}10 \% \\
\text { meat-bone } \\
\text { meal }\end{array}$ \\
\hline Gan 18 & 62 & 68 & 56 & 71 & 68 & 53 \\
Gan Li 27/3 & 42 & 45 & 63 & 52 & 47 & 45 \\
Gan 7 & 52 & 57 & 59 & 55 & 50 & 48 \\
Gan 112 & 30 & 32 & 35 & 38 & 31 & 32 \\
GL 01 & 102 & 123 & 128 & 117 & 110 & 107 \\
GL 02 & 91 & 109 & 106 & 120 & 117 & 94 \\
GL 03 & 98 & 125 & 126 & 130 & 115 & 93 \\
GL 04 & 107 & 123 & 133 & 116 & 120 & 109 \\
Mean & $73 \mathrm{a}$ & $85 \mathrm{bc}$ & $88 \mathrm{c}$ & $87 \mathrm{c}$ & $82 \mathrm{~b}$ & 73 \\
\hline
\end{tabular}

Means marked with the same letters do not differ significantly at $\alpha=0.05$

mycelium growth rate, depending on the applied additive, ranged from 5.2 to $6.3 \mathrm{~mm}$ per day. Similar results were described by Jo et al. (2013a), as in their study conducted on oak sawdust substrate with a $20 \%$ addition of rice bran growth increment was $5.3 \mathrm{~mm}$ per day. In turn, in substrates supplemented with food waste compost it ranged from 3.6 to $5.3 \mathrm{~mm}$ per day. Similar results (3.2$5.8 \mathrm{~mm}$ per day) were recorded also by Yang et al. (2003) on substrate from black locust sawdust with an addition of malt (stillage grain), wheat bran and ground rice. In studies conducted by Gonzalez-Matute et al. (2002) on substrate from sunflower husks supplemented with wheat bran and malt the growth rate of mycelium ranged from 5.33 to $5.88 \mathrm{~mm}$ per day. A much greater growth rate of mycelium was reported by Azizi et al. (2012), when comparing $5 \%$ and $10 \%$ wheat bran additions and $2.5 \%$ and $5 \%$ additions of maltose recorded the fastest mycelium growth of Reishi mushrooms (10.6 mm per day) on the substrate with an $10 \%$ addition of bran and $2.5 \%$ addition of maltose. Differences in mycelium growth rates were probably connected with different compositions of substrates used in the experiments and different $\mathrm{C} / \mathrm{N}$ ratios.

In the presented experiments strains of $G$. lucidum exhibited a much faster growth rate than isolates collected from nature (Fig. 1). The mean mycelium growth rates of isolates on substrates supplemented with organic additives varied greatly and after 14 days of incubation ranged from 33 to $66 \mathrm{~mm}$. In turn, growth rates in strains were very similar (from 106 to $118 \mathrm{~mm}$ ) and it was only in the GL 02 strain a weaker mycelium growth was observed in comparison to the other strains. The varied mycelium growth in different Ganoderma strains were also reported by Siwulski and Sobieralski (2001) and Sobieralski and Grzebielucha (2005). Differences were also found in a study by Sukarno et al. (2004), in which commercial mycelium of G. lucidum was characterised by a more rapid growth rate than isolates coming from natural localities.

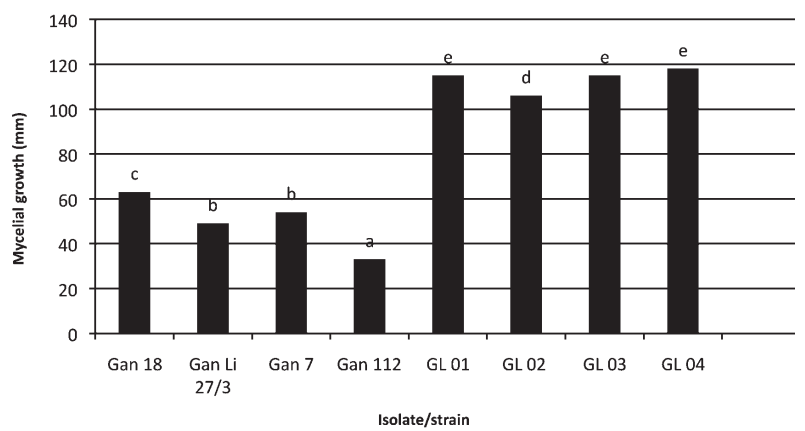

Fig. 1. Mean mycelium growth of isolates and strains of Ganoderma lucidum on oak sawdust substrate supplemented with different organic additives.

\section{Biological efficiency}

Results of numerous studies show that supplementation of growing substrate containing sawdust has a positive effect on its biological efficiency. It was confirmed in the presented experiments (Table 2). Four out of the applied enriching additives (wheat bran, rye grain, ground soy and ground rapeseed) showed an advantageous effect on biological efficiency of tested isolates and Ganoderma strains. At the addition of bone meal to the growing substrate no positive effect was observed on the biological efficiency of this mushroom. Mean biological efficiency, depending on the applied additive, was $10-22 \%$. Three of the compared substances exhibited $22 \%$ biological efficiency. In turn, biological efficiency on the substrate supplemented with meat-an-bone meal was identical as on the control substrate and amounted to $10 \%$.

According to Chen (2004), in culture on the substrate containing sawdust a $5-25 \%$ addition of bran was used. In the presented experiments wheat bran was added at 20\%. Erkel (2009a), when using a 20\% addition of wheat bran to oak sawdust substrate reported a slightly lower biological efficiency of Ganoderma (18.6\%) than that found in this presented study. Even worse results 
Table 2. Biological efficiency of isolates and strains of Ganoderma lucidum on oak sawdust substrate supplemented with different organic additives

\begin{tabular}{lcccccc}
\hline & \multicolumn{5}{c}{ Organic additives } \\
\cline { 2 - 6 } $\begin{array}{c}\text { Isolates/ } \\
\text { strains }\end{array}$ & $\begin{array}{c}0 \% \\
\text { control }\end{array}$ & $\begin{array}{c}20 \% \\
\text { wheat bran }\end{array}$ & $\begin{array}{c}25 \% \\
\text { rye } \\
\text { grain }\end{array}$ & $\begin{array}{c}7 \% \\
\text { ground } \\
\text { soy }\end{array}$ & $\begin{array}{c}10 \% \\
\text { ground } \\
\text { rapeseed }\end{array}$ & $\begin{array}{c}\text { meat- bone } \\
\text { meal }\end{array}$ \\
\hline Gan 18 & 7 & 13 & 15 & 14 & 13 & 8 \\
Gan Li 27/3 & 6 & 14 & 16 & 14 & 12 & 7 \\
Gan 7 & 6 & 15 & 14 & 15 & 12 & 7 \\
Gan 112 & 8 & 18 & 18 & 19 & 13 & 9 \\
GL 01 & 13 & 38 & 40 & 42 & 34 & 17 \\
GL 02 & 12 & 28 & 27 & 29 & 23 & 16 \\
GL 03 & 10 & 25 & 20 & 23 & 23 & 9 \\
GL 04 & 10 & 27 & 23 & 24 & 21 & 10 \\
Mean & $9 \mathrm{a}$ & $22 \mathrm{~b}$ & $22 \mathrm{~b}$ & $22 \mathrm{~b}$ & $22 \mathrm{~b}$ & $10 \mathrm{a}$ \\
\hline
\end{tabular}

Means marked with the same letters do not differ significantly at $\alpha=0.05$

were recorded by that author when using a $20 \%$ addition of maize and rice bran, as biological efficiency in those cases was $16.3 \%$ and $13.56 \%$. The same author (Erkel 2009b) on poplar sawdust substrate with a $20 \%$ addition of wheat bran obtained $17.2 \%$ efficiency. In a study by Azizi et al. (2012) biological efficiency of Reishi mushrooms grown on poplar sawdust substrate with a $10 \%$ addition of wheat bran and a $5 \%$ addition of maltose extract was higher, amounting to $18.68 \%$. This could have been caused by an addition of maltose extract or the property of the tested fungal strain.

Peksen and Yakupoglu (2009), when growing two strains of Ganoderma on hornbeam sawdust substrate with an $18 \%$ addition of wheat bran, depending on the strain obtained biological efficiency ranging from 13 to 20\%. Gurung et al. (2012), depending on the applied substrate additions of two types of sawdust, recorded from $6.9 \%$ to $12.19 \%$ efficiency. Those authors recorded the highest biological efficiency (22.62\%) for the substrate of sawdust from Nepalese alder (Alnus nepalensi) with a $10 \%$ addition of gram flour. In turn, a 10\% addition of wheat bran resulted in a slightly lower biological efficiency of Reishi mushrooms (14.58\%).

Stamets (2000), in cultivation of G. lucidum recommends a maximum $15 \%$ addition of rice bran to the substrate. Mishra and Singh (2008) investigated the effect of wheat and rice bran (2.5\% and 5\%) on yielding of three Reishi isolates grown on substrates from different types of agricultural waste (coir, wheat straw, chickpea straw and mustard straw). The best results were recorded for a $5 \%$ rice bran addition to wheat straw substrate. Biological efficiency in the experiments conducted by those authors ranged from $10 \%$ to $17 \%$ and it was lower than that presented in this study (22\%). For the addition of rice bran ( 5 and 10\%) to the substrate containing wheat straw the efficiency recorded for different Ganoderma isolates efficiency ranged from 5.85 to 20\% (Mishra and Singh, 2012). A much greater biological efficiency (29.9\%) after the application of a $10 \%$ addition of rice bran was recorded by Veena and Pandey (2011). Results reported by those authors could have been influenced by the different composition of the substrate used in their experiments.

Supplementation of plant residue, i.e. sugar cane, coir and chips, with fish processing waste made it possible to obtain biological efficiency of Reishi mushrooms at $0.92-12.95 \%$. Increasing the level of fish waste in the growing substrate resulted in the efficiency of 0.92 $4.63 \%$, while an addition of meat-and-bone meal (10\%) provided 10\% efficiency (Lakshimi, 2013).

Most additives used in the presented study in oak sawdust substrate resulted in mean biological efficiency of $22 \%$, which indicates very good properties of these materials in growing Reishi musrooms. The highest biological efficiency (42\%) among the tested isolates and strains of Ganoderma was recorded for the GL01 strain grown on substrate supplemented with ground soy.

In the presented study strains of G. lucidum exhibited much greater biological efficiency that the tested isolates (Fig. 2). The greatest biological efficiency (37\%) was recorded for the GL01 strain, while it was lowest (14\%) for isolates Gan 18, Gan Li 27/3 and Gan 7. In a study by Peksen and Yakupoglu (2009), mean biological

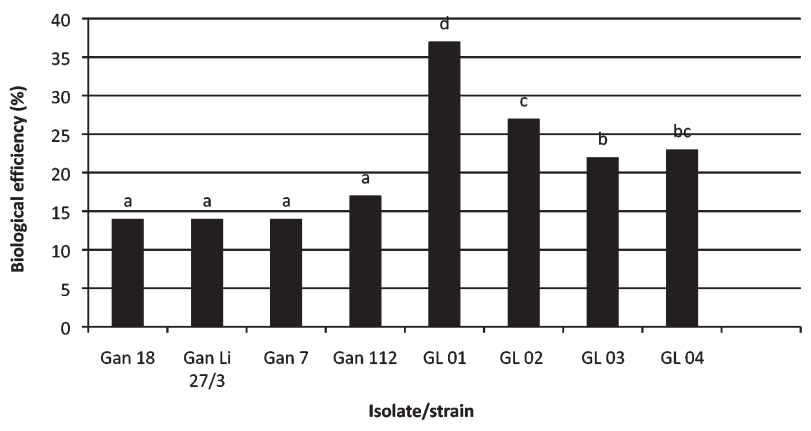

Fig. 2. Mean biological efficiency of isolates and strains of Ganoderma lucidum on oak sawdust substrate supplemented with different organic additives. 
efficiency of the two compared strains of Ganoderma did not differ significantly and in both cases was approx. $24 \%$.

Conducted experiments confirmed that organic waste materials may be successfully used in growing Reishi mushrooms and have a significant effect on mycelium growth and their biological efficiency. In the presented study mycelium growth and biological efficiency depended also on the used isolates and strains of Reishi mushrooms.

Results of our experiments and those reported by other researchers concerning mycelium growth and biological efficiency differ considerably depending on the type of used substrate and applied supplements. In most cases supplementation of growing substrates had a positive effect on growing results of G. lucidum. This problem needs to be investigated in further research. Obviously the selection of growing substrate and additives will first of all be determined by their availability and price.

\section{REFERENCES}

Azizi, M., M. Tavana, M. Farsi and F. Oroojalian 2012 Yield performance of Lingzhi or Reishi medicinal mushroom, Ganoderma lucidum (W.Curt.Fr.) P. Karst. (Higher Basidiomycetes), using different waste materials as substrates. Int. J. Med. Mushr., 14: $521-527$

Batra, P., A.K. Sharma and R. Khajuria 2013 Probing Lingzhi or Reishi medicinal mushroom Ganoderma lucidum (Higher Basidiomycetes): a bitter mushroom with amazing health benefits. Int. J. Med. Mushr., 15: 127-143

Boh, B., M. Berovic, J. Zhang and L. Zhi-Bin 2007 Ganoderma lucidum and its pharmaceutically active compounds. Biotechnol. Annu. Rev., 13: 265-301

Chang, S. T. and P. G. Miles 2004 Mushrooms Cultivation, Nutritional Value, Medicinal Effect, and Environmental Impact. CRC Press, pp. 357-372

Chen, A. W. 2004 Growing Ganoderma mushrooms. Mushroom growers' handbook. In "Oyster mushroom cultivation", Mushr. World, Korea, pp. 224-234

Chen, A. W. 1999 Cultivation of the medicinal mushroom Ganoderma lucidum (W. Curt.: Fr.) P. Karst. (Reishi). Int. J. Med. Mushr., 1: 263-282

Chen, A. W. 2002 Natural-log cultivation of the medicinal mushroom Ganoderma lucidum (Reishi). In "Mushroom Biology and Mushroom Products" ed. by J. E. Sanchez et al., UAEM, pp. $445-452$

Curvetto, N., R. Gonzalez-Matute, D. Figlas and S. Delmastro 2002 Sunflower seed-based medium for growth of Ganoderma spp. In "Mushroom Biology and Mushroom Products" ed. by J. E. Sanchez et al., UAEM, pp. 205-211

Erkel, E. I. 2009a The effect of different substrate mediums on yield of Ganoderma lucidum (Fr.) Karst. J. Food Agric. Environ., 7: 841-844

Erkel, E. I. 2009b Yield performance of Ganoderma lucidum (Fr.) Karst cultivation on substrates containing different protein and carbohydrate sources. Afric. J. Agric. Res., 49: $1331-1333$

Fanadzo, M., D. T. Zireva, E. Dube and A. B. Mashingaidze 2010 Evaluation of various substrates and supplements for biological efficiency of Pleurotus sajor-caju and Pleurotus ostreatus. Afric. J. Biotechnol., 9: 2756-2761

Gonzalez-Matute, R., D. Figlas, R. Devalis, S. Delmastro and N. Curvetto 2002 Sunflower seed hulls as a main nutrient source for cultivation Ganoderma lucidum. Micologia Int., 14: $19-24$

Gurung, O. K., U. Budathoki and G. Parajuli 2012 Effect of Different Substrates on the Production of Ganoderma luci- dum (Curt.:Fr.) Karst. Our Nature, 10: 191-198

Hsieh, C. and F. C. Yang 2004 Redusing soy residue for the solidstate fermentation of Ganoderma lucidum. Biores. Technol., 91: 105-109

Jo, E. Y., J. L. Cheon and J. H. Ahn 2013a Effect of Food Waste Compost on the Antler-Type Fruiting Body Yield of Ganoderma lucidum. Mycobiology, 41: 42-46

Jo, E. Y., J. Y. Choi, J. W. Choi and J. H. Ahn 2013b Influence of Food Waste Compost on the Yield and Mineral Content of Ganoderma lucidum, Lentinula edodes, and Pholiota adipose Fruiting Bodies. Mycobiology, 41: 210-213

Ke, L., Q. Wu and D. Zhang 2011 Bioconversion of rape straw into a nutritionally enriched substrate by Ganoderma lucidum and yeast. Afric. J. Biotechnol., 10: 5648-5653

Lai, T., Y. Gao and S. Zhou 2004 Global marketing of medicinal Ling Zhi mushroom Ganoderma lucidum (W. Curt.: Fr.) Lloyd (Aphyllophoromycetideae) products and safety concerns. Int. J. Med. Mushr., 6: 219-230

Lakshmi, S. S. 2013. In vivo utilization of seafood processing wastes for cultivation of the medicinal mushroom (Ganoderma lucidum) using agro-industrial waste. Asian J. Pharm. Clin. Res., 6: 51-54

Mishra, K. K. and R. P. Singh 2012 Evaluation of Indigenous Ganoderma lucidum Isolates of Uttarakhand for Growth and Yield. J. Mycol. Plant Pathol., 42: 136-140

Mishra, K. K. and R. P. Singh 2008 Evaluation of Substrate for Production of Ling Zhi or Reishi Medicinal Mushroom Ganoderma lucidum (W. Curt.: Fr.) P. Karst. (Aphyllophoromycetideae). Int. J. Med. Mushr., 10: 379-383

Paterson, R. R. M. 2006 Ganoderma - A therapeutic fungal biofactory. Phytochemistry, 67: 1985-2001

Peksen, A. and G. Yakupoglu 2009 Tea waste as a supplement for the cultivation of Ganoderma lucidum. World J. Microbiol. Biotechnol., 25: 611-618

Philippoussis, A., G. Zervakis and P. Diamantopoulou 2001 Bioconversion of lignocellulosic wastes through the cultivation of the edible mushrooms Agrocybe aegerita, Volvariella volvacea and Pleurotus spp. World J. Microbiol. Biotechnol., 17: $191-200$

Rai, R. D., S. Kamal and S. K. Singh 2004 Effect of Wheat Bran Supplementation to the Sawdust Substrate on Mycelial Growth Rate and Production of Extracellular Degradative Enzymes by the Medicinal Reishi Mushroom Ganoderma lucidum (W. Curt.: Fr.) Lloyd (Aphyllophoromycetideae). Int. J. Med. Mushr., 6: 375-382

Sanodiya, B. S., G. S. Thakur, R. K. Baghel, G. B. Prasad and P. S. Bisen 2009 Ganoderma lucidum: a potent pharmacological macrofungus. Curr. Pharm. Biotechnol., 10: 717-742

Siwulski, M., K. Sobieralski and J. Mańkowski 2010 Comparison of mycelium growth of selected species of cultivated mushrooms on textile industry wastes. Acta Sci. Pol. Hort. Cult., 9: $37-43$

Siwulski, M. and K. Sobieralski 2001 Mycelium growth and yielding of two strains of Ganoderma lucidum (Fries) Karst. Cultivated on sawdust substrate. Veg. Crops Res. Bull., 54: 101-104

Skalicka-Woźniak, K., J. Szypowski, R. Łoś, M. Siwulski, K. Sobieralski, K. Głowniak and A. Malm 2012 Evaluation of polysaccharides content in fruit bodies and their antimicrobal activity of four Ganoderma lucidum (W. Curt.: Fr.) P. Karst. Strains cultivated on different wood type substrates. Acta Soc. Bot. Pol., 81: 17-21

Sobieralski, K. and I. Grzebielucha 2005 Comparison of mycelium growth of two strains of Ganoderma lucidum (Fries) Karst. Cultivated on sawdust substrate. Sodininkyste ir Darzininkyste, 24: 336-340

Sobieralski, K. and I. Grzebielucha 2006a Wpływ temperatury na plon i zawartość suchej substancji owocników lakownicy lśniącej Ganoderma lucidum (Fr.) Karst. Folia Hort. (Supplement), 2: 144-147

Sobieralski, K. and I. Grzebielucha 2006b Wpływ temperatury na wzrost grzybni trzech odmian lakownicy lśniącej Ganoderma lucidum (Fr.) Karst. Folia Hort. (Supplement), 2: 148-151 
Stamets, P. 2000 Growing Gourmet and Medicinal Mushrooms. 3rd ed. Ten Speed Press, Berkeley, USA

Sukarno, N., A. Aini, V. Sumarna, E. Rohaeti and L.K. Darusman 2004 Development of Ganoderma lucidum on Soft and Hard Wood Logs and Determination of Organic Germanium and Ganoderic Acid Content of the Fruiting Body Produced. $J$. Mush. Sci. Prod., 2: 157-162

Veena, S. S. and M. Pandey 2011 Paddy straw as a substrate for the cultivation of Lingzhi or Reishi medicinal mushroom, Ganoderma lucidum (W. Curt.: Fr.) P. Karst. in India. Int. J. Med. Mushr., 13: 397-400

Wasser, S. P. 2011 Current finding, future trends, and unsolved problems in studies of medicinal mushrooms. Appl. Microbiol. Biotechnol., 89: 1323-1332

Wasser, S. P. 2002 Medicinal mushrooms as a source of antitumor and immunomodulating polysaccharides. Appl. Microbiol. Biotechnol., 60: 258-274

Wasser, S. P. 2005 Reishi or Ling Zhi (Ganoderma lucidum). In "Encyclopedia of Dietary Supplements" ed. by P. M. Coates, M. R. Blackman, G. M. Cragg, M. Levine, J. Moss and J. D. White, Marcel Dekker, New York, pp. 603-622

Xu, Z., X. Chen, Z. Zhong, L. Chen and Y. Wang 2011 Ganoderma lucidum Polysaccharides: Immunomodulation and Potential Anti-Tumor Activities. Am. J. Chin. Med., 39: 15-27

Yang, F. C., C. Hsieh and H. M. Chen 2003 Use of stillage grain from a rice-spirit distillery in the solid state fermentation of Ganoderma lucidum. Process Biochem., 39: 21-26

Zhou, X. W., K. Q. Su and Y. M. Zhang 2012 Applied modern biotechnology for cultivation of Ganoderma and development of their products. Appl Microbiol Biotechnol., 93: 941-963 